Bolm. Zool., Univ. S. Paulo 6: $79-88,1983$

\title{
ON SOME STRUCTURES IN NANNOTRIGONA (SCAPTOTRIGONA) POSTICA LATREILLE (HYMENOPTERA, MELIPONINAE).
}

Luci Rolandi Bego Departamento de Biologia, Faculdade de Filosofia. Ciências e Letras de Ribeirāo Preto (USP). Present address: Depto. de Ecologia do Instituto de Biociências da USP - C.P. 11230 - São Paulo.

Dércio Simões

Universidade Estadual Paulista " "Júlio de Mesquita Filho" " - Campus Universitário de Rio Claro - Instituto de Biociências.

Ronaldo Zucchi Departamento de Biologia (Setor de Ecologia), Faculdade de Filosofia, Ciências e Letras de Ribeirão Preto - USP.

(Recebido em 04.02.1980)

\section{RESUMO}

No presente trabalho, estudamos o ciclo de desenvolvimento das glândulas hipofaringeanas, glândulas de cera e ovários de operárias de Scaptotrigona postica, em colónias normal e órfã.

As glândulas hipofaringeanas de operárias da colônia normal apresentaram um ciclo de desenvolvimento e regressão bem definido. As glândulas hipofaringeanas das operárias da colónia órfã entraram num processo de regressão, a partir do quinto dia de vida das operárias, não apresentando seu ciclo normal, provavelmente, devido à falta da atividade de arrovisionadoras dos alvéolos de cria. Em condição normal, os ovários, as glândulas de cera e glândulas hípofaringeanas, encontraram-se desenvolvidos, na mesma época. Este fato indica que a atividade de todas essas estruturas estão intimamente correlacionadas. Em operárias da calônia órfã, a coincidência de funções foi observada somente em relação as glândulas de cera e ovários.

\section{ABSTRACT}

The present paper deals with the developmental aspects of some internal structures (hypopharyngeal glands, wax glands and ovaries) of the stingless bee - Scaptotrigona postica in normal and orphan colonies.

The hypopharyngeal glands of workers in normal (queen headed) colonies presentend a well defined cycle of development and regression. Otherwise, in an orphan colony the same gland started degeneration from the fifth day of 
life on without performing the normal gland cycle. This is probably an outcome of the absence of brood cells to be fed. In a normal colony, ovaries and wax glands were developed in concurrency. This indicates that the activities of these structures (including the hypopharyngeal gland) are strongly correlated. In the orphan colony such coincidence of functions was observed in relation to wax glands and ovaries only.

\section{MATERIAL AND METHODS}

A NC of Scaptotrigona pastica was transfered to an observation hive (Sakagami \& Zucchi, 1963; Sakagami 1966) and provided with a regular temperature of $28^{\circ} \mathrm{C}$ throughout the experiment.

At five days' intervals, the callow-bees were individually marked and introduced in the hive. When the first introduced batch iwasi 30 days old the marked bees were taken and fixed in Dietrich (20 bees for each age). This provided samples ranging from 5 to 30 days old and enabled to correlate age with gland activity. The methodological details are in Bego (1974).

The activity of the hg (figs. 1 and 2) was checked through the diameter of its acini. For each bee 10 acini were measured and to evaluate the hg development the following classe were used: A (7-9); B (10-12); C (13-15); D (16-18); E (19-21); F (16-18); G (13-15); H $(10-12)$; I (7-9). The numerals inside the brackets are the measures in microscopic ocular divisions, where one division equals $2.27 \mu \mathrm{m}$.

The development of ov (Table 2, Fig. 3) was evidenced through the length of the larger oocyte found and the following develomental stages were determined: A (incipient - 6) undeveloped; B (7-15) beginning of development; C (16-35) developed; D (35 or more) fully developed; $\mathbf{E}-$ degenerated. The numerals represent, as already explained, size in mocroscopic ocular divisions, where one division equals $0,022 \mathrm{~mm}$.

The development of wg (table 4) was only indirectly studied through the quantification to the wax plates found in the tergal abdominal segments and classified as: A (no wax); B (little); C (moderate amount); D (large and well formed wax plates).

To control adult bee feeding, the content of digestive system (crop, ventricle and rectum) was analyzed (table 1) and the system of classification adopted was: P (pollen present) ; H (honey present) ; PH (pollen and honey present); E (empty).

Similar procedures were followed in the case of workers from the OC. In this case, the colony was mantained orphan for 20 days and then received the samples of individually marked bees. Further procedures were exactly as already explained.

\section{RESULTS AND DISCUSSION}

\section{1 - Hypopharyngeal gland (figs. 1,2)}

The development of the hg in the NC workers presented two distinct phases: gradual increasing until 15 days old and progressive degeneration the latter starting around the twentieth day or life and well marked at the thirtieth day. 


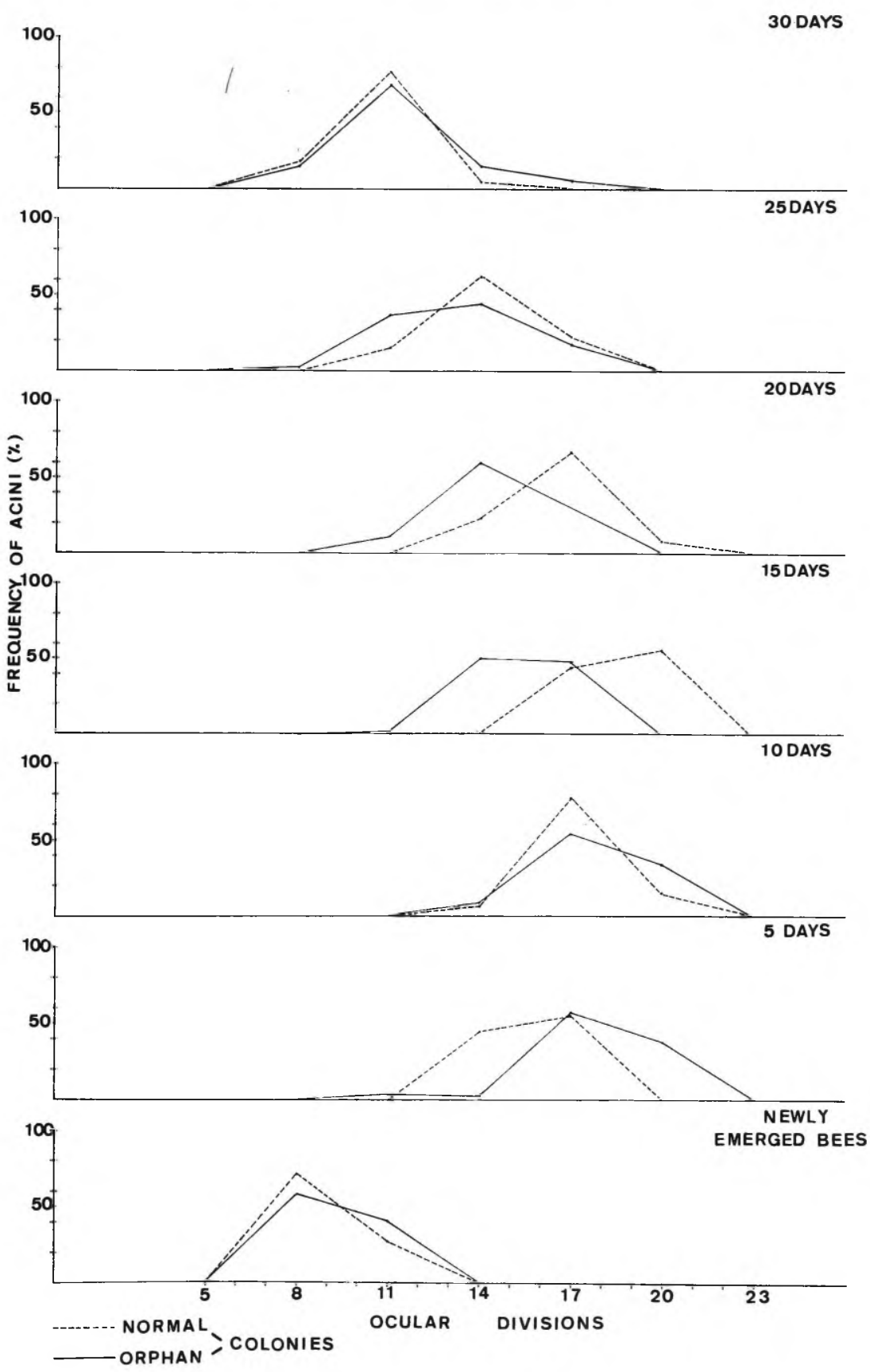

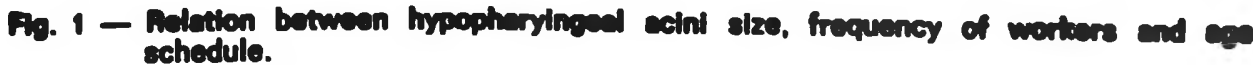



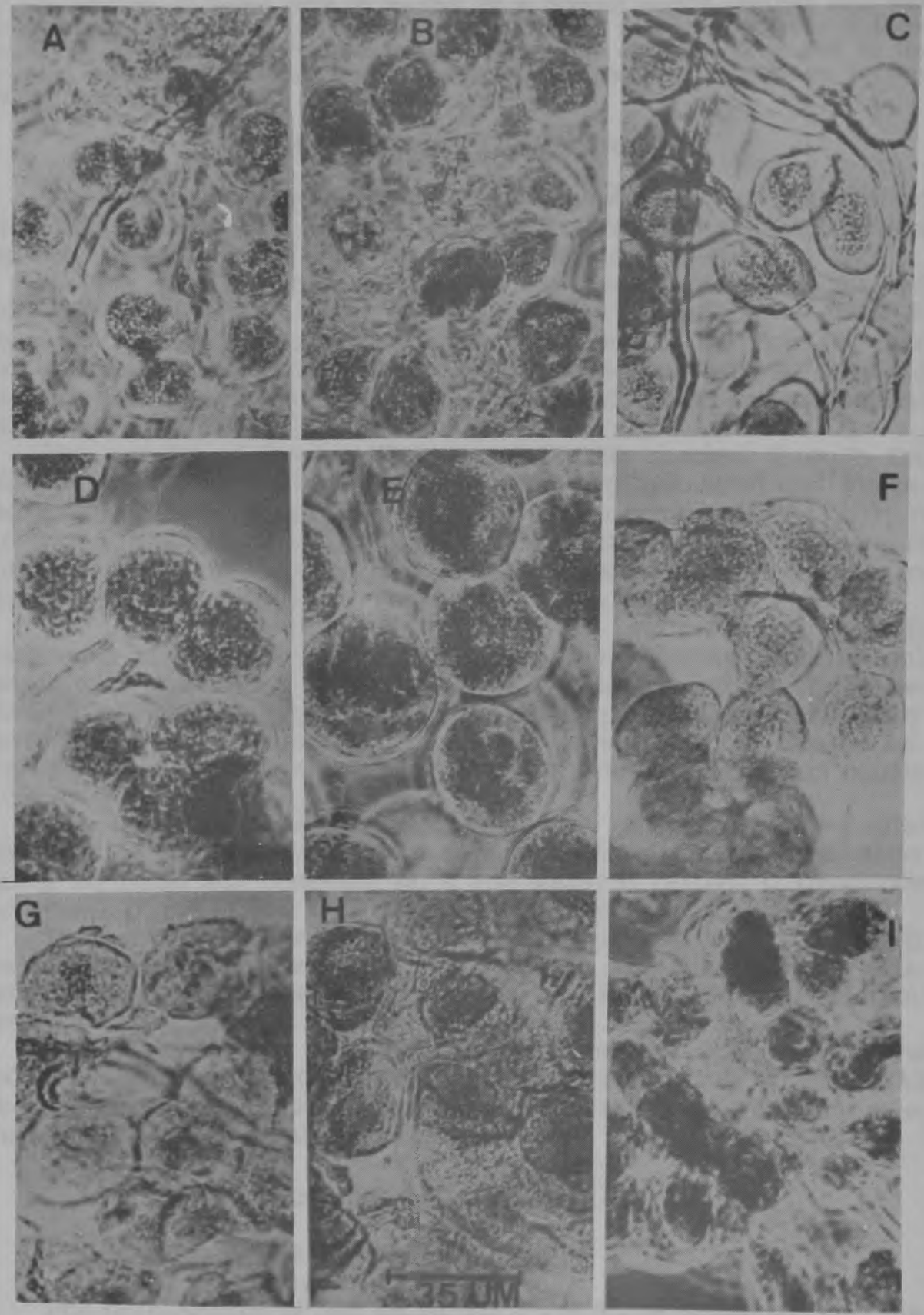

Fig. 2 - Developmental stages (A-I) of the hypopharyngeal glands (see text for exple nation). 

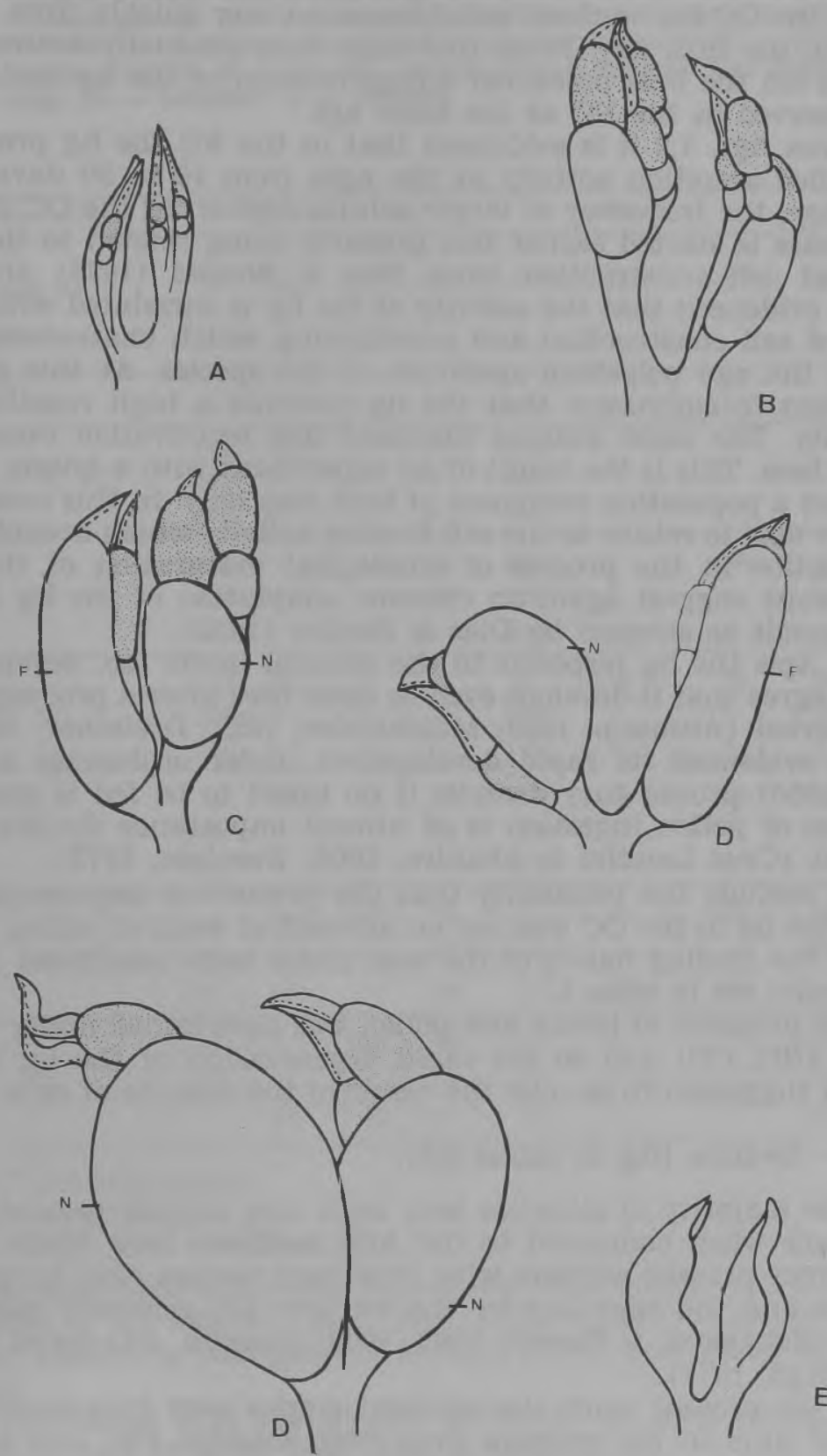

$1 \mathrm{MM}$

Fig. 3 - Ovary patterns in Scaptotrigona postica workers. A - undeveloped; B - Beginning of development; C - developed; D - fully developed: $E$ - degenerated: $F$ - Functional egg: $\mathrm{N}-$ Nutritive egg (see text for explanation). One
ocular division is igual $0.022 \mathrm{~mm}$. 
In the OC the workers' acini increased very quickly from the emergence to the fifth day. From this stage they gradually decrease. When 30 days old the bees presented a degeneration of the hg similar to the one observed in the NC at the same age.

From figs. 1,2 it is evidenced that in the NC the $\mathrm{hg}$ presented an intensified secretion activity at the ages from 10 to 20 davs, since at this stage, the frequency of larger acini is higher. In the OC the regression phase is started earlier this probably being related to the absence of brood cell construction since Dias \& Simões (1972) and Simões (1974) evidenced that the activity of the hg is correlated with the task of brood cell construction and provisioning which characterizes a sten among the age polyetism spectrum of the species. At this point it is important to emphasize that the hg presents a high reactivation potentiality. The same authors disclosed this reactivation even in older (field) bees. This is the result of an experiment with a queen, sufficient food and a population composed of field bees only. In this case the field bees are able to return to the cell feeding activity which occupies an earlier position in the process of ethological maturation of the species. The results suggest again an extreme adaptation of the hg to the colonial needs as stressed by Dias \& Simões (1972).

In Apis the hg responds to the colonial needs too. Several investigators agree that it develops even in older bees after a prolonged orphanage period (Altmann, 1950; Müssbichler, 1952; Dreischer, 1956). Hess (1942) evidenced its rapid development under orphanage and Dreischer (1956) proved they dwindle if no brood to be fed is present. The presence of pollen ingestion is of utmost importance for the hg development (Cruz Landim \& Akahira, 1966; Zucoloto, 1973).

To exclude the possibility that the precocious degeneration observed in the hg in the OC was not on account of want of pollen, we investigated the feeding habits of the bees under both conditions (NC, OC). The results are in table 1.

The presence of honey and pollen was ascertained under both conditions (NC, OC) and so the rapid degeneration of the $\mathrm{hg}$ under OC is again suggested to be only the result of the absence of cells to be fed.

2 - Ovaries (fig. 3; tables 2,3).

The majority of stingless bees until now studied present a marked difference when compared to the Apis mellifera bees. Many species of the former present workers with developed ovaries even in queen-right colonies and the eggs laid by the workers are generally eaten by the queen (Sakagami \& Zucchi, 1963, 1966; Akahira, Sakagami \& Zucchi, 1970; Bego, 1977).

In the present study the workers' ovaries were fully developed from 10 to 25 days in the workers from both colonies (NC and OC). From this age on they degenerate (table 2, fig. 3).

Confirming previous observations (in litt.) in both colonies of $\mathbf{S}$. postica two kinds of worker born eggs were produced, that is, the large and round type (nutritive egg) and the thinner one (functional egg). Both are laid by the workers at the already fed cell's upper internal margin. The thinner eggs are, at well determined epochs, placed inside 
Table 1 - Digestive tract content and age schedule among workers of Scaptotrigona postica under normal and orphan conditions. Digestive tract content: P - pollen present; $\mathbf{H}$ - honey present; $\mathrm{PH}$ - pollen and honey present; E - empty. Organs where content was found: A crop; B - venticle; C - rectum.

\begin{tabular}{lllllllll}
\hline colonies & & Normal & & & Orphan \\
\hline age of & P & PH & H & E & P & PH & H & E \\
workers & & & & & & & & \\
\end{tabular}

\begin{tabular}{|c|c|c|c|c|c|c|c|c|}
\hline 0 & + & + & + & + & + & + & + & + \\
\hline \multirow{3}{*}{5} & $12 \mathrm{~A}$ & $8 \mathrm{~A}$ & - & - & $20 \mathrm{~A}$ & - & - & - \\
\hline & $20 \mathrm{~B}$ & - & - & - & $20 \mathrm{~B}$ & - & - & - \\
\hline & $20 \mathrm{C}$ & - & - & - & $20 \mathrm{C}$ & - & - & - \\
\hline \multirow{3}{*}{10} & $17 \mathrm{~A}$ & - & $2 A$ & $I A$ & $18 \mathrm{~A}$ & - & $2 A$ & - \\
\hline & $19 \mathrm{~B}$ & - & - & $1 B$ & $18 \mathrm{~B}$ & - & - & $2 B$ \\
\hline & $20 \mathrm{C}$ & - & - & - & $20 \mathrm{C}$ & - & - & - \\
\hline \multirow{3}{*}{15} & $11 \mathrm{~A}$ & $9 \mathrm{~A}$ & - & - & - & $10 \mathrm{~A}$ & $7 \AA$ & $3 A$ \\
\hline & $20 \mathrm{~B}$ & - & - & - & $16 \mathrm{~B}$ & - & - & $4 B$ \\
\hline & $20 \mathrm{C}$ & - & - & - & $14 \mathrm{C}$ & $4 \mathrm{C}$ & - & $2 \mathrm{C}$ \\
\hline \multirow{3}{*}{20} & $7 \mathrm{~A}$ & $8 \mathrm{~A}$ & $4 \mathrm{~A}$ & $1 \mathrm{~A}$ & $2 \mathrm{~A}$ & $8 \mathrm{~A}$ & $6 \mathrm{~A}$ & $4 \mathrm{~A}$ \\
\hline & $19 \mathrm{~B}$ & - & - & IB & $8 \mathrm{~B}$ & - & - & $12 \mathrm{~B}$ \\
\hline & $20 \mathrm{C}$ & - & - & - & $17 \mathrm{C}$ & $1 \mathrm{C}$ & $1 \mathrm{C}$ & $1 \mathrm{C}$ \\
\hline \multirow{3}{*}{25} & - & $5 A$ & $14 \mathrm{~A}$ & $1 \mathrm{~A}$ & - & $1 \mathrm{~A}$ & $14 \mathrm{~A}$ & $5 A$ \\
\hline & $12 \mathrm{~B}$ & - & - & $8 B$ & $1 B$ & - & - & $19 \mathrm{~B}$ \\
\hline & $15 \mathrm{C}$ & $2 \mathrm{C}$ & - & $3 c$ & $4 \mathrm{C}$ & $1 \mathrm{C}$ & $1 \mathrm{C}$ & $14 \mathrm{C}$ \\
\hline \multirow{3}{*}{30} & - & - & $16 \mathrm{~A}$ & $4 \mathrm{~A}$ & - & - & $8 \mathrm{~A}$ & $12 \mathrm{~A}$ \\
\hline & $1 B$ & - & - & $19 \mathrm{~B}$ & - & - & - & $20 B$ \\
\hline & - & $3 C$ & $3 c$ & $14 \mathrm{C}$ & $4 \mathrm{C}$ & - & - & $16 \mathrm{C}$ \\
\hline
\end{tabular}

cells (as all the queen eggs) and in this case they originate the majority of the males of the species (Beig, 1972). The nutritive egg is deprived of nucleus (Akahira, Sakagami \& Zucchi, 1970) and incapable of development.

The functional eggs are largely produced by younger bees while the nutritive ones by older bees (Fig. 3, table 3).

These results fit well with the observations (Simões, 1974) disclosing that the functional eggs are more directly related to determined age schedules during which the bees more frequently are engaged in brood care activities. Otherwise, the nutritive ones are produced at ages were the workers are mainly involvid in tasks other than brood rearing. 
Table 2 - Ovary development and age workers in normal and orphan colonies. Ovary patterns: A (undeveloped); B (beginning of development); C (developed); D (fully developed); E (degenerated).

\begin{tabular}{|c|c|c|c|c|c|c|c|}
\hline \multirow[t]{2}{*}{ colonies } & \multicolumn{2}{|c|}{$\begin{array}{l}\text { age of } \\
\text { workers }\end{array}$} & \multicolumn{3}{|c|}{ ovary patterns } & \multirow[b]{2}{*}{$\mathbf{E}$} & \\
\hline & & $\mathbf{A}$ & $\mathbf{B}$ & $\mathbf{C}$ & $\mathbf{D}$ & & \\
\hline Normal & $\begin{array}{r}0 \\
5 \\
10 \\
15 \\
20 \\
25 \\
30\end{array}$ & $\begin{array}{l}20 \\
12 \\
- \\
- \\
- \\
-\end{array}$ & $\begin{array}{r}-8 \\
5 \\
- \\
- \\
-\end{array}$ & $\begin{array}{r}- \\
-5 \\
3 \\
3 \\
2 \\
-\end{array}$ & $\begin{array}{r}- \\
10 \\
8 \\
8 \\
5 \\
-\end{array}$ & $\begin{array}{r}- \\
- \\
9 \\
9 \\
13 \\
20\end{array}$ & freq. \\
\hline Orphan & $\begin{array}{r}0 \\
5 \\
10 \\
15 \\
20 \\
25 \\
30\end{array}$ & $\begin{array}{r}20 \\
8 \\
2 \\
- \\
- \\
- \\
-\end{array}$ & $\begin{array}{l}\overline{12} \\
1 \\
- \\
- \\
-\end{array}$ & $\begin{array}{l}- \\
5 \\
3 \\
2 \\
-\end{array}$ & $\begin{array}{r}\overline{-} \\
\overline{12} \\
8 \\
3 \\
2 \\
-\end{array}$ & $\begin{array}{r}\overline{-} \\
\overline{9} \\
15 \\
18 \\
20\end{array}$ & freq. \\
\hline
\end{tabular}

Table 3 - Frequency of functional (F) and nutritive (N) eggs in relation to worker's age in normal and orphan colonies.

\begin{tabular}{lllllll}
\hline & Normal & \multicolumn{3}{c}{ colonias } & \multicolumn{2}{c}{ Orphan } \\
\cline { 2 - 7 } $\begin{array}{l}\text { age of } \\
\text { workers }\end{array}$ & N & F & N types & F \\
\hline 10 & 4 & 6 & 4 & 8 & freq. \\
15 & 1 & 7 & 8 & 0 & 0 \\
20 & 7 & 1 & 3 & 0 & 8
\end{tabular}

3 - Wax glands (table 4)

Concerning the wg development our results show that in NC or OC wax is produced from the fifth to the twenty fifth day of life of the workers. The amount produced is, however, intensified about the tenth day.

The only detectable difference between both conditions (NC and $O C)$ is the increased frequency of bees 5 days old bearing large abdominal wax scales under $O C$. The fact suggests that at this age schedule the gland has already attained its developmental peak which conversely implies to the wg the same pattern as observed for the hg development. 
Table 4 - Wax presence in the dorsal part of worker's abdomen in relation to age of workers in normal and orphan colonies: A (no wax); B (little); C (moderate amount); D (large and well formed wax plates).

\begin{tabular}{|c|c|c|c|c|c|c|}
\hline \multirow[t]{2}{*}{ colonies } & \multirow{2}{*}{$\begin{array}{c}\text { age of } \\
\text { workers }\end{array}$} & \multicolumn{4}{|c|}{ wax quantification } & \\
\hline & & $\boldsymbol{A}$ & B & $\mathbf{C}$ & D & \\
\hline Normal & $\begin{array}{r}0 \\
5 \\
10 \\
15 \\
20 \\
25 \\
30\end{array}$ & $\begin{array}{r}20 \\
2 \\
3 \\
3 \\
6 \\
14 \\
20\end{array}$ & $\begin{array}{r}-11 \\
2 \\
6 \\
10 \\
6 \\
-\end{array}$ & $\begin{array}{l}-6 \\
4 \\
1 \\
4 \\
-\end{array}$ & $\begin{array}{r}-1 \\
11 \\
10 \\
- \\
-\end{array}$ & freq. \\
\hline Orphan & $\begin{array}{r}0 \\
5 \\
10 \\
15 \\
20 \\
25 \\
30\end{array}$ & $\begin{array}{r}20 \\
1 \\
1 \\
4 \\
15 \\
20\end{array}$ & $\begin{array}{r}-7 \\
2 \\
12 \\
7 \\
5 \\
-\end{array}$ & $\begin{array}{r}-8 \\
3 \\
3 \\
5 \\
-\end{array}$ & $\begin{array}{r}-5 \\
14 \\
4 \\
4 \\
-\end{array}$ & freq. \\
\hline
\end{tabular}

\section{REFERENCES}

AKAHIRA, Y; Sakagami, S.F.; Zucchi, R. 1970 - Die Nahreier von der Arbeiterinen einer stachellosen Biene, Trigona (Scapotrigona) postica, die von der Konigin kurz vor der eigenen Eiablage geffressen werden. Zool. Anz. $185(1-2): 85-93$.

ALTMANN, G. 1950 - Ein Sexualwirkstoff bei Honigbienen. Z. Bienenforsch 1 (2) : 24-32.

BEGO, L. R. 1974 - Estudos sobre regulação social em Nannotrigona (Scaptotrigona) postica Latreille, com especial referência a aspectos morfo-funcionais (Hymenoptera, Apidae, Meliponinae). Dissertação de Mestrado. Depto. de Genética. Fac. Med. Rib. Preto (USP), 92 pp.

BEGO, L.R. 1977 - Aspectos da regulação social em Nannotrigona (Scaptotrigona) postica Latreille (Hym., Apidae, Meliponinae). Tese de Doutoramento. Depto. de Genética. Fac. Med. Rib. Preto (USP), $180 \mathrm{pp}$.

BEIG, D. 1972 - The production of males in queenright colonies of Trigona (Scaptotrigona) postica L. (Hym., Apoidea). Jour. Apic. Res. 11(1): 33-39.

CRUZ LANDIM, C. 1967 - Estudo comparativo de algumas glândulas das abelhas (Hymenoptera, Apoidea) e respectivas implicações evolutivas. Arq. Zool. S. Paulo 15(3): 177-290.

CRUZ LANDIM, C. e AKAHIRA, Y. 1966 - Influência da alimentação no desenvolvimento de algumas glândulas de Trigona (Scaptotrigona) postica L. (Hym. Apoidea). Papéis Avulsos. Dep. Zool. S. Paulo 19(6) : 63-78.

CRUZ LANDIM, C. e PUGA, F.R. 1967 - Presença de substâncias lipídicas nas glândulas do sistema salivar de Trigona (Hym., Apoidea). Papéis Avulsos Zool. S. Paulo 20(7) : 65-74.

DIAS, L.B.L. e SIMÕES, D. 1972 - Relação entre estrutura etária (normal e anormal) de colônias de Scapotrigona postica Latreille e desenvolvimento glandular (Hymenoptera: Apidae). Homenagem a Warwick E. Kerr. Rio Claro. São Paulo, pp. 135-137.

DREISCHER, H. 1956 - Untersuchungen über die Arbeitstatigkeit und Drüsenentwicklung altersbestimmter Bienen im weisellosen. Volk. Zool. Jo. (Physiologie) $66(2 / 3): 429-472$.

HESS, G. 1942 - Uber den Einflusse der Weisellosigkeit und des Fruchtbarkeitsvitamins $\mathrm{E}$ auf die Ovarien der Bienenarbeiterin. Beihfte Schweiz. Bienenzitg $1(2): 33-110$. 
MUSSBICHLER, A. 1952 - Die Bedeutung ausserer Einflüsse und der Corpora allata bei der Afterweiselentstehung von Apis mellifica. $Z$. Vergl. Physiol. 43(3) : 207-221.

SAKAGAMI, S.F. 1966 - Techniques for the observation of behavior and social organization of stingless bees by using a special hive. Papéis Avulsos. Zool. S.P. 19: 151-162.

SAKAGAMI, S.F.; BEIG, D.; ZUCCHI, R. and AKAHIRA, Y. 1963 - Occurrence of ovary-development workers in queenright colonies of stingless bees. Rev. Bras. Biol. $23(2)$ : 115-129.

SAKAGAMI, S.F. and ZUCCHI, R. 1963 - Oviposition process in a stingless bee, Trigona (Scaptotrigona) postica Latr. (Hym). Studia Entomologica 6(1-4): 497-510.

SAKAGAMI, S.F. e ZUCCHI, R. 1966 - Estudo comparativo do comportamento de várias espécies de abelhas sem ferrão, com especial referência ao processo de aprovisionamento e postura das células. Ciência e Cultura 18(3): 283-296.

SAKAGAMI, S.F. and ZUCCHI, R. 1974 - Oviposition behavior of two dwarf stingless bees, Hypotrigona (Leurotrigona) muelleri and H. (Trigonisca) duckei, with notes on the temporal articulation of oviposition process in stingless Bees. Jour. Fac. Sci. Hok. Univ. VI, Zool. 19(2) : 361-421.

SIMỐES, D. 1974 - Estudos sobre regulaçāo social em Nannotrigona (Scaptotrigona) postica Latreille, com especial referência a aspectos comportamentais. Dissertação de Mestrado. Fac. Med. Rib. Preto (USP), 92 pp.

ZUCOLOTO, F.S. 1973 - Estudos da nutriçāo em Mannotrigona (Scaptotrigona) postica (Hymenoptera-Apidae). Tese de Doutoramento. Fac. Fil. Ciênc. Let. Rib. Preto. SP, 163 pp.

\section{ACKNOWLEDGEMENTS}

We thank Prof. Dr. Shôichi F. Sakagami for his generous help. The research received grants from the Fundação de Amparo à Pesquisa do Estado de São Paulo and Conselho Nacional de Desenvolvimento Científico e Tecnólogico. 